\title{
Effect of some nutrients on growth, Yield and fruit quality of "Wonderful" cultivar pomegranate
}

\author{
A. N. Abd El-wahed *, A. M. Abd -Alrazik, and S. M. Khalifa \\ Department of Horticulture, Faculty of Agriculture, Al-Azhar University, Nasr city, Cairo, Egypt. \\ *Corresponding author E-mail: abdelwahedabdelwahed485.el@azhar.edu.eg (A. Abd El-wahed)
}

\begin{abstract}
Cracking, sunburn and poor coloring of fruit are the main problems facing pomegranate. (Punica granatum L.) "Wonderful" cultivar since they play a major role in fruit quality. The current study was carried out during the two successive seasons of 2018 and 2019 on ten years old trees grown in sandy soil in a private orchard located at El Bostan, El- Behera Governorate, Egypt. The effect of B, Ca, Zn, $\mathrm{Cu}$ and $\mathrm{Mn}$ applied at full bloom stage and 6 weeks after full bloom on "Wonderful" trees was studied. The results indicated that the highest value of vegetative growth was obtained from calcium chloride at $4 \%$ and zinc sulphate at $0.4 \%$ compared with other treatments. Spraying trees with calcium chloride at $4 \%$ and zinc sulphate at $0.4 \%$ decreased the percentages of fruit drop, cracking, sunburn and increased significantly yield $(\mathrm{kg} /$ tree) and fruit physical parameters such as fruit weight $(\mathrm{g})$, fruit size $\left(\mathrm{cm}^{3}\right)$ and firmness in comparison to other treatments. Fruit biochemical characteristics such as TSS $\%$, ascorbic acid $\mathrm{mg} / 100 \mathrm{ml}$, Anthocyanin and enhancing coloration have been also positively affected by using this treatment compared with other treatments. It might be recommended that foliar spraying "Wonderful" trees with calcium chloride at $4 \%$ and zinc sulphate at $0.4 \%$ at full bloom stage and 6 weeks after full bloom where, decreased cracking, sunburn and gave the highest values of yield $(\mathrm{kg} /$ tree) and fruit quality under the conditions of the experiment in located at El Bostan, El- Behera Governorate, Egypt.
\end{abstract}

Keywords: pomegranate, Sunburn, coloration, Anthocyanin, nutrients, Cracking

\section{INTRODUCTION}

Pomegranate (Punica granatum L.) belonging to the Punicaceae family, is one of the favorite table fruits grown in tropical and sub-tropical regions. This plant is native of Iran and is extensively cultivated in the Mediterranean countries like Spain, Morocco, Egypt, Iran and Afghanistan. Wonderful cultivar is the most important pomegranate cultivar grown in El-Behera governorate. According to the Egyptian ministry of agriculture statistics (2018), the total area devoted for pomegranate in Egypt was 80109 Feddan and fruiting area was 76924 Feddan producing about 630000 tons with an average for 8.19 tons /Feddan. El-Behera governorate represents about $60 \%$ of the total area and production. Quality assessment of pomegranate fruit is based on important external attributes such as size, shape and color. However, because fruit skin color does not indicate the extent of ripening or its readiness for consumption, internal attributes such as color, total soluble solids and acidity are also considered in assessing readiness for harvest to meet market requirements (Kader, 2006 and Holland et al., 2009). Wonderful pomegranate confronts a lot of serious problems such as fruit cracking, sunburn, lack of coloration in the appropriate color of the peel and pulp and lowest average of yield tons / Feddan.

Fruit cracking is one of the main problems facing the pomegranate producers. It resulted in huge losses to farmers by reducing the total yield up to $30-50 \%$. It also resulted in a significant deterioration in fruit quality which in turn led to a non-marketable yield (Bankar and Prasad 1992, Elsalhy 1996 and Singh and Kingsly 2006). The factors associated with fruit cracking might be high evapotranspiration, low relative air humidity $(\mathrm{RH})$, water imbalance and sharp temperature fluctuation in day and night during fruit growth and development (Abdelrahman, 2010).

sunburn occurs as well mainly where air temperature and the number of sunny hours are high during the ripening period. Sunburn also occurs when cool or mild weather is abruptly followed by hot, sunny weather. Severe sunburn alters the cuticle even more, and damages both the epidermal and sub epidermal tissues. Cell walls get thicker. Intercellular phenols increase, and the structures of plastids and thylakoids change (Barber and Sharpe, 1971; Andrews and Johnson, 1996, 1997). Sadeghzadeh (2013) reported that foliar spray of zinc as sulfate reduced percent cracking besides improving fruit yield probably due to its effect on water uptake and transport besides influencing 
activities of enzymes involved in protein, carbohydrate and nucleic acid metabolism. Also Hegazi et al. (2014) obtained lowest percentage of fruit creaking in Manfaloty and Wonderful pomegranates cultivars with spraying by $\mathrm{CaCl}_{2}$ treatment compared with the control. Lal et al. (2011) reported that spraying Jyoti, Dholka, Kandhari, Bedana and G-137 pomegranate varieties with Borax at 50 ppm at 15th May (fruit set) and 15th June (fruit active development stage) decreased percentage of fruit splitting as compared with control. Also, copper plays an indispensable role in regulating several metabolic and physiological processes of plants. It helps in the utilization of iron during chlorophyll synthesis Harris and Lavanya (2016).

Treatments of some nutrients such as (B, $\mathrm{Ca}, \mathrm{Zn}, \mathrm{Cu}$ and $\mathrm{Mn}$ ) on wonderful pomegranate plants might increase fruiting potential, fruit superiority and marketable fruits. Hence, this work is designed to discover the result of foliar spraying wonderful pomegranate trees with $\mathrm{B}, \mathrm{Ca}, \mathrm{Zn}, \mathrm{Cu}$ and $\mathrm{Mn}$ on adjusting fruit creaking $\%$, sunburn and increasing vegetative growth, Yield, fruit Physical and Chemical Characteristics.

\section{MATERIALS AND METHODS}

This study was carried out during the two consecutive seasons of 2018 and 2019 on 10 years old "Wonderful" pomegranate trees grown in sandy soil in a private orchard at El Bostan, El- Behera Governorate, Egypt, "Wonderful" pomegranate trees. The trees planted at $3 \times 4$ meters of spacing. All trees are irrigated using drip irrigation system. The chosen trees for the experimentation were similar in vigor and subjected to the same cultural practices that followed in the farm. The tested trees were sprayed with $\mathrm{B}, \mathrm{Ca}, \mathrm{Zn}$, $\mathrm{Cu}$ and $\mathrm{Mn}$. They studied their effects on vegetative growth, yield, fruit Physical and chemical characteristics of "Wonderful" pomegranate trees at full bloom stage and 6 weeks after full bloom for the two seasons to study their effects on growth, fruit set, fruit yield / tree, cracking, sunburn, physical and chemical properties of fruits.

\section{The treatments:}

$\mathrm{B}, \mathrm{Ca}, \mathrm{Zn}, \mathrm{Cu}$ and $\mathrm{Mn}$ were applied individually at full bloom stage and 6 weeks after full bloom as foliar spray on the trees as follows:

T1: Control (the trees were Sprayed with water only).
T2: Boric acid at concentration 0.5\%.

T3: Boric acid at concentration $1 \%$

T4: Calcium chloride at concentration $2 \%$

T5: Calcium chloride at concentration $4 \%$

T6: Zinc sulphate at concentration $0.2 \%$

T7: Zinc sulphate at concentration $0.4 \%$

T8: Copper sulphate at concentration $0.2 \%$

T9: Copper sulphate at concentration $0.4 \%$

T10: Manganese sulphate at concentration $0.2 \%$

T11: Manganese sulphate at concentration $0.4 \%$

A complete randomized block design was adopted in this experiment with 11 treatments where each treatment had three replicates with three trees per treatment. Each tree was received $7 \mathrm{~L}$ of the applied solution plus $5 \mathrm{~cm}$ per liter of 20 to avoid the surface tension except those of control treatment which sprayed with water only

\section{Measurements:}

\section{Vegetative growth}

\section{Shoot length (cm.):}

Twenty shoots/tree were devoted from the beginning of growth measure the shoot length $(\mathrm{cm})$ after it stopped increasing in growth

\section{Number of leaves/ shoots:}

Number of leaves/ shoots were recorded at cessation of growth of each season on Twenty shoots per tree

\section{Leaf area $\left(\mathrm{cm}^{2}\right)$ :}

Leaf area $(\mathrm{cm})$ was measured by using the following equation as mentioned by Ahmed and Morsy (1999) Leaf area $=0.41$ (Length of leaf $x$ Width of leaf $)+1.83=\ldots \ldots . \mathrm{cm}$

\section{Canopy volume $\left(\mathrm{cm}^{3}\right)$ :}

Tree height and width were measured in Oct. of each season to calculate canopy volume according to Turrel (1946) using the following formula:

\section{Canopy volume $=0.5236 \times \mathrm{HD}^{2}$}

where $\mathrm{H}=$ tree height and $\mathrm{D}=$ tree width

\section{The fruiting: -}

\section{Fruit set percentage}

Four branches (two years old) similar in growth were chosen, one branch in each original direction and twelve shoots per each 
main branch were tagged at the balloon stage of the flower. At blooming, all opened flowers/ shoot was counted. After the end of fruit set, the number of fruit set was recorded and fruit set percentage was calculated by using Hifny et al. (2013) equation.

Initial fruit set $\%=($ Total No. of set fruits /shoot)/ (Total No. of opened flowers/shoot) $\times$ 100

\section{Retained fruits percentage:}

Number of retained fruits were counted at harvest and calculated by using Hifny et al. (2013) equation:

Retained fruits $\%=($ No. of retained fruits at harvest/shoot)/ (No. of initial set fruits/shoot) $\times 100$

\section{Fruit drop percentage:} (2013)

It was recorded according to Hifny et al.

Fruit drop $\%=($ No. of fruits at fruit set - No of retained fruits at harvest)/ (No. of fruits at fruit set) $\times 100$

\section{Yield:}

Harvesting achieved on ( $5^{\text {th }}$ October for each season), yield (Kg/tree) was recorded.

\section{Yield increase than control (\%)}

Yield increment than untreated treatment percentage was calculated by using Abdelnaby et al. (2019) equation.

Yield increase than control $(\%)=$ (Fruit yield (kg) /treatment - Fruit yield (kg)/ control)/ (Fruit yield (kg)/ control) $\times 100$

\section{Fruit cracking}

Percentage of fruit cracking / tree was calculated in three stages (15 days before harvest time, at harvest time and 15 days after harvest time) by using Elakkad et al. (2016) equation

Fruit cracking $=$ No. of cracked fruits $/$ Total No. of fruits $x 100$

\section{Sunburn}

At harvest time, the number of fruits per tree in each treatment were counted and also each fruit was visually rated depending on the severity of damage by sunburn and calculated as a percentage relative to the total number of fruits on the tree by the following equation: Hegazi et al. (2014)

Sunburn $(\%)=$ No. of Sunburn fruits/ Total No. of fruits $\times 100$

\section{Marketable and Unmarketable fruits}

according to Hegazi et al. (2014)

Marketable fruits $\%=$ Total N. of fruits (No. of cracked + sunburn fruits) $\times 100$.

Unmarketable $\%=($ No. of cracked + sunburn fruits)/ (Total No. of fruits) x 100

\section{Fruit physical characteristics:}

At harvest, samples of fifteen fruits of each tree replicated were devoted to determine the following fruit characteristics: Fruit weight (g), fruit size $\left(\mathrm{cm}^{3}\right)$ fruit length $(\mathrm{cm})$, fruit diameter $(\mathrm{cm})$. fruit firmness $\left(\mathrm{g} / \mathrm{cm}^{2}\right)$ by using a digital pressure tester $\left(\mathrm{g} / \mathrm{cm}^{2}\right)$, Peel thickness $(\mathrm{cm})$ and Juice volume $\mathrm{cm}^{3}$

\section{Fruit biochemical characteristics:}

Total soluble solids percentage (TSS \%).

It was estimated by abbe digital refractometer, according to A.O.A.C. (2000)

\section{Total acidity percentage.}

It was determined as citric acid by titration with a solution of 0.1 N., $\mathrm{Na} \mathrm{OH}$, using phenolphthalein as an indicator according to A.O.A.C. (2000). The results were calculated as gm. per $100 \mathrm{ml}$ of juice.

\section{Total soluble solids/ Acid ratio.}

It was determined as the following equation:

Total soluble solids/ Acid ratio = TSS (\%) / Total acidity (\%).

\section{Ascorbic acid (Vitamin C) content.}

The amounts of Ascorbic acid in juice samples were determine by the use of 2,6 dichlorophenol indophenol dye and $0.2 \%$ oxalic acid as a substrate and $5 \mathrm{ml}$. of filtered aliquot. It was calculated as $\mathrm{mg} / 100 \mathrm{ml}$. of juice as reported by Ruck (1969).

\section{Total anthocyanin in peel and juice of fruit}

Peel anthocyanin content (mg/ $100 \mathrm{~g})$ was assessed according to the method of Fuleki and Francis (1968). Total anthocyanin in juice of fruit was determined according to Ranganna (1979).

The color (hue angle).

It was determined by using a Minolta colorimeter type (CR-400/410) for the estimation of $a, b$ and hue angle $\left(h^{\circ}\right)$. Hue angle $\left(h^{\circ}=\operatorname{arc} \tan b^{*} / a^{*}\right)$ determines the red, yellow, green, blue, purple, or intermediate colors between adjacent pairs of these basic colors. Hue angle $\left(0^{\circ}=\right.$ red-purple, $90^{\circ}=$ 
yellow, $180^{\circ}=$ bluish-green, $270^{\circ}=$ blue), as described by McGuire (1992).

\section{Statistical analysis:}

A completely randomized block design was followed and the results were statistically analyzed using F-value test. The means were compared by L.S.D at the level of $5 \%$ probability according to Snedecor and Cochran (1980). The obtained data were calculated using (COSTAT) program according to Stern (1991)

\section{RESULTS AND DISSCTION}

\section{Effect of foliar spraying with B, Ca, Zn, Cu and $\mathrm{Mn}$ on vegetative growth}

The data in Table (1) illustrated that the application of some nutrients $(\mathrm{B}, \mathrm{Ca}, \mathrm{Zn}, \mathrm{Cu}$ and $\mathrm{Mn}$ ) on Wonderful pomegranate gave a significantly increased of shoot length $(\mathrm{cm})$ compared with control treatment in both studied seasons. The highest length of shoot was obtained from calcium chloride at $4 \%$ followed in descending by zinc sulphate at $0.4 \%$ then zinc sulphate at $0.2 \%$ and calcium chloride $2 \%$. On the other hand, the lowest length of shoot was obtained from "control" during 2018 and 2019 seasons. The results are in agreement with those of other workers such as Sutanu et al. (2017) who found that foliar application of Ca at $3 \%+\mathrm{B}$ at $0.25 \%$ in Punica granatum $L$. increased shoot length as compared with control. Also, Ibrahim (2013) found that foliar application of olive with Znso4 at 30 ppm on 21 April increased shoots length $(\mathrm{cm})$ as compared with the control. Shoot length increased due to treatments with calcium which was playing an important role in the component of plant tissue and took part in the protection of plant cells Elmer et al. (2007). The spraying of Znso4 plays also an important role to activate up to 300 enzymes such as Peptidase, Proteinase, Enolase and also needs a plant in the formation of the amino acid Tryptophan, which consists of hormone indole acetic acid (IAA) which is essential for cell elongation Barker and Pilbeam (2007).

It is obvious from Table (1) that, the number of leaves per shoot increased by all treatments (B, Ca, $\mathrm{Zn}, \mathrm{Cu}$ and $\mathrm{Mn}$ ) in both seasons as compared with control. The largest number of leaves per shoot was obtained from calcium chloride at $4 \%$ followed descending by zinc sulphate at $0.4 \%$ then zinc sulphate at $0.2 \%$ and calcium chloride $2 \%$ in the two studied seasons. On the other hand, the lowest length of shoot was obtained from "control" during 2018 and 2019 seasons. The results are in agreement with those of other workers such as Bakeer (2016) which indicated that foliar application of Manfalouty pomegranate trees by $\mathrm{CaCl}_{2}$ at $2 \%$ at four times (The first week of March, May, July and September) increased number of leaves as compared with control. Also, Singh et al. (2005) observed that the foliar application of zinc $(0.25 \%$ and $0.5 \% \mathrm{ZnSO} 4)$ at two months from transplanting significantly increased the number of leaves per plant in papaya. The increase in the number of leaves is due to the increase in shoot length resulting from spraying with compounds $(\mathrm{B}, \mathrm{Ca}, \mathrm{Zn}, \mathrm{Cu}$, $\mathrm{Mn})$. Where calcium is important for proper cell division, cell elongation, cell wall development (Ashraf et al., 2018). As well as zinc is involved in the synthesis of tryptophan which is a precursor to the synthesis of indole acetic acid, thus increasing tissue growth and development. It has an important role in starch metabolism, acts as a cofactor for many enzymes, and affects photosynthesis reaction, DNA metabolism, and protein biosynthesis. (Alloway, 2008).

Data presented in Table (1) displayed that, there were significant differences between spraying nutrient treatments $(\mathrm{B}, \mathrm{Ca}, \mathrm{Zn}, \mathrm{Cu}$ and $\mathrm{Mn}$ ) on leaf area, whereas, all treatments increased leaf area $\left(\mathrm{cm}^{2}\right)$ compared to that of control treatment. Trees treated by calcium chloride at $4 \%$ specifically led to significant increase of the largest leaf area followed in descending by zinc sulphate at $0.4 \%$ then calcium chloride $2 \%$ and zinc sulphate at $0.2 \%$. The results are in agreement with those of other workers such as Alrawi et al. (2014) who found that spraying Salemy pomegranate cv., with $\mathrm{Cacl}_{2}$ at $100 \mathrm{ppm}$ in the last week of May and first week of June increased leaf area $\left(\mathrm{cm}^{2}\right)$ as compared with control. On the other hand, Hasani et al. (2012) suggested that application of $\mathrm{ZnsO} 4$ at $0.3 \%$ of pomegranate tree increased leaf area $\left(\mathrm{cm}^{2}\right)$ compared with the control. Dickinson et al. (2003) reported that the role of zinc in DNA and RNA metabolism, in cell division, and protein synthesis has been documented for many years.

Results in Table (1) showed that there were significant differences between spraying nutrient treatments $(\mathrm{B}, \mathrm{Ca}, \mathrm{Zn}, \mathrm{Cu}$ and $\mathrm{Mn})$ on canopy volume $\left(\mathrm{m}^{3}\right)$ whereas, all treatments increased canopy volume $\left(\mathrm{m}^{3}\right)$ compared to that of control treatment. The highest Canopy volume $\left(\mathrm{m}^{3}\right)$ was obtained from calcium chloride at $4 \%$ followed descending by zinc sulphate at $0.4 \%$ in the two studied seasons. On the other hand, the lowest canopy volume $\left(\mathrm{m}^{3}\right)$ was obtained from "control" during 2018 
and 2019 seasons. The results are in agreement with those of other workers such as Bakeer (2016) who indicated that foliar application of Manfalouty pomegranate trees at $\mathrm{CaCl}_{2}$ at $2 \%$ at four times (The first week of March, May, July and September) increased plant height (m) and plant canopy volume $(\mathrm{m} 3)$ and leaf area $\left(\mathrm{cm}^{2}\right)$ as compared with control. Also, Ibrahim (2013) found that foliar application of olive trees with Znso4 at 30 ppm on 21 April increased Plant height as compared with the control (m) and plant canopy volume $\left(\mathrm{m}^{3}\right)$. The increase in the canopy volume $\left(\mathrm{m}^{3}\right)$ is due to the increase in shoot length, number of leaves and leaf area $\left(\mathrm{cm}^{2}\right)$ resulting from spraying with compounds $\mathrm{B}, \mathrm{Ca}, \mathrm{Zn}, \mathrm{Cu}$ and $\mathrm{Mn}$.

It could be concluded that foliar spraying of Wonderful pomegranate trees at full bloom stage and 6 weeks after full bloom with calcium chloride and zinc sulphate stimulated the shoot length, number of leaves per shoot and leaf area as well as canopy volume $\left(\mathrm{m}^{3}\right)$ in comparison to the of other foliar treatments or control.

\section{Effect of foliar spraying with B, Ca, Zn, Cu and Mn on fruiting}

The results in Table (2) indicated that spraying each $\mathrm{B}, \mathrm{Ca}, \mathrm{Zn}, \mathrm{Cu}$ and $\mathrm{Mn}$ was able to significantly increase the percentages of initial and fruit retention and decrease fruit drop as compared with that of untreated trees (control) in a consistent manner in both seasons. Results also showed that the highest percentages of initial fruit set and fruit retention of the first and second seasons were obtained from spraying trees with calcium chloride at $4 \%$ followed by zinc sulphate at $0.4 \%$. On the other hand, the lowest percentages of initial fruit set and fruit retention were obtained from control. The results are in full agreement with those of other workers such as Ahmed et al. (2014) who found that spraying of "Manfalouty" pomegranate trees at the first week of March, May and June with $\mathrm{CaCl}_{2}$ at $2 \%$ increased percentages of initial fruit set, fruit retention, number of fruits / trees as compared with control. Also, Parmar et al. (2014) found that foliar application of guava tree with zinc sulfate at concentrations ( 0.2 and 0.4$)$ before blooming increased fruit set $\%$, fruit retention $\%$ compared with the control. The role of $\mathrm{Ca}$ in stopping the formation of abscission zone between fruit pedicles and bearing branches as well as regulating the activity of enzymes and photosynthesis (Tony and John, 1994; Mignani et al., 1995 and Jackman and Stanley, 1995)., Ashraf et al. (2013) also indicated that application of zinc improves the citrus fruit yield and this might be due to involvement of zinc in photosynthesis, activation of enzyme systems, protein synthesis and carbohydrate translocation.

The results showed that all treatments significantly decreased fruit drop percentage as compared with the control. The highest fruit drop percentage was obtained from control. On the other hand, the lowest fruit drop percentage of the first and second seasons was obtained from spraying trees with calcium chloride at $4 \%$ followed by zinc sulphate at $0.4 \%$. In this line Nijjar (1985) demonstrated that a tentative explanation for the decreased fruit drop percentage due to calcium and zinc sprays may be due to the improvement in the formation of cellulose and lignin. These materials are required for building plant structure or preventing the abscission layer formation and consequently, the reduction in pre-harvest fruit dropping. Yagodin (1990) also reported that zinc plays many important regulatory roles in plant development. It activates many enzymes involved in plant metabolism and enhances the biosynthesis of some organic foods and IAA as well as stimulates cell division, cell enlargement, water absorption and nutrient transport. It is also important for strengthening cell wall and reducing the formation of the abscission zone which leads to decreased fruit drop percentage.

Data in Table (2) displayed clearly that both yield as ( $\mathrm{kg} /$ tree) and increment percentage in relation to the control have responded significantly to all used treatments as compared with control treatment during the two seasons of study. Furthermore, the greatest statistical values of both yield parameters were resulted from "Wonderful" pomegranate trees being sprayed with calcium chloride at $4 \%$ followed by zinc sulphate at $0.4 \%$. On the other hand, the lowest yield as (kg/tree) was obtained from control. This increase in yield as (kg/tree) and increment percentage is due to increased initial fruit set, fruit retention (\%), fruit weight and decreased fruit drop (\%). These above results agreed with the findings of Sheikh and Manjula (2012) who found that foliar application of pomegranate cultivar 'Ganesh' with $\mathrm{CaCl}_{2}$ at $1 \%$ at preharvest increased yield $\mathrm{kg} /$ tree as compared with control. Hamouda et al., (2016) reportedas well that foliar spraying Manfalouty pomegranate with $\mathrm{Zn}$ at $2000 \mathrm{ppm}$ at mid of March, April and June increased yield kg / tree as compared with control. 
We can come to conclusion that foliar application with $\mathrm{B}, \mathrm{Ca}, \mathrm{Zn}, \mathrm{Cu}$ and $\mathrm{Mn}$ at different levels increased initial and fruit retention percentages and yield $(\mathrm{kg} /$ tree) in comparison with that of untreated tree (control). The best foliar application which gave the highest values was obtained with calcium chloride at $4 \%$ compared with control and other treatments.

\section{Effect of foliar spraying with B, Ca, Zn, Cu and $\mathrm{Mn}$ on fruit cracking, sunburn, marketable and unmarketable fruits:}

\section{Fruit cracking}

The results in Table (3) indicate that the percentage of fruit cracking / tree was calculated during three stages 15 days before harvest time, at harvest time and 15 days after harvest time. The general trend of the results was to increase the percentage of cracking with the advancement of the fruits in ripening, but this percentage in the increase was low due to the use of $\mathrm{B}, \mathrm{Ca}, \mathrm{Zn}, \mathrm{Cu}$ and $\mathrm{Mn}$ during the three stages. The $1^{\text {st }}$ stage (15 days before harvest time), $2^{\text {nd }}$ stage (at harvest time) and $3^{\text {rd }}$ stage (15 days after harvest time) all treatments in general significantly decreased percentage of fruit cracking / tree as compared to the control during the two studied seasons. The highest fruit cracking percentages during the three stages in the first and second seasons were obtained from control. In this respect, the lowest significant fruit cracking percentage during the three stages (15 days before harvest time, at harvest time and 15 days after harvest time) was obtained from calcium chloride at $4 \%$ followed by zinc sulphate at $0.4 \%$, copper sulphate at $0.4 \%$ and calcium chloride at $2 \%$ in both studied seasons. The results confirmed by Randhawa et al. (1958) who reported that cracking occurs after heavy rainfalls, followed by a period of drought. Nutrients like calcium, zinc, copper, molybdenum and manganese are involved in some physiological processes during the fruit growth period, and their deficiency results in fruit cracking. The previous positive action of calcium on reducing fruit splitting of Wonderful pomegranate trees might be attributed to their important roles in strengthening cell wall through building calcium pectates in the middle lamella as well as stabilization of membrane systems and strengthening the bonds between epidermal and other fruit cells. Calcium is also responsible for reducing the abscission zone formation among fruits and branches as well as regulating the mechanisms of photosynthesis and proteins (Poovaiah, 1986; Tony and John, 1994 and Jackman and
Stanley, 1995). The beneficial effect of $\mathrm{Ca}$ in promoting the biosynthesis of sugars and plant pigments as well as checking the uptake of water was accompanied with enhanced maturity and improved fruit quality (Yagodin, 1990 and Mengel et al., 2001). The beneficial effects of zinc on controlling water absorption and nutrient uptake as well as enhancing the biosynthesis of the natural hormone namely IAA surely reflected on reducing fruit cracking $\%$, Yagodin (1990). Moreover, zinc is responsible for strengthening cell wall and reducing the formation of the abscission zone (Mengel et al., 2001).

\section{Effect of foliar spraying with B, Ca, Zn, Cu and $\mathrm{Mn}$ on sunburn, marketable and unmarketable fruits}

The results in Table (4) indicate that the percentage of sumburn, marketable and unmarketable fruits. Sunburn injury is common on fruits due to high solar radiation levels and air temperatures and low relative humidity. Excess absorbed energy is the greatest contributor to cell death and sunburn. The incidence and severity of sunburn depends upon climatic factor, cultivars, hormonal, nutritional and soil moisture (Schrader et al., 2003). Sunburn can be prevented only by shutting off direct sunlight, or by wrapping the fruit with paper, or by other means, but these methods are not practical because of high labor costs, and they have not come into widespread use (Sadamatsu, 1982).

The results in Table (4) showed that all treatments in general significant decreased percentage of sunburn and unmarketable fruit as compared to the control during 2018 and 2019 seasons. In this respect, all treatments in general significantly increased percentage marketable fruit as compared with control in a consistent manner in both seasons. The lowest significant percentage of sunburn and unmarketable fruit was obtained from calcium chloride at $4 \%$ followed by calcium chloride at $2 \%$, zinc sulphate at $0.4 \%$ and zinc sulphate at $0.2 \%$ in the first and second seasons. So, the highest percentage of marketable fruit was obtained from these treatments (calcium chloride at $4 \%$ followed by calcium chloride at $2 \%$, zinc sulphate at $0.4 \%$ and zinc sulphate at $0.2 \%$ ). The results confirmed by Glenn et al. (2002) who reported that crimson seedless grapevines treated with plant protection as $\mathrm{CaCo}$ were less prone to sunburn damage than untreated ones and this is due to reducing both fruit temperature and exposure to ultraviolet. Also, Ahmed et al. (2011) found 
that $\mathrm{CaCo}$ stimulated plant metabolism through enhancing photosynthesis and formation of plant pigments in favor of enhancing quality of the berries.

It is concluded that foliar application with $\mathrm{B}, \mathrm{Ca}, \mathrm{Zn}, \mathrm{Cu}$ and $\mathrm{Mn}$ at different ranges increased marketable fruits and decreased fruit cracking (\%) at different stages, sunburn (\%) and unmarketable fruits in comparison with that of untreated trees (control). The best foliar application was calcium chloride at $4 \%$ compared with the control and other treatments.

Effect of foliar spraying with B, Ca, Zn, Cu and $\mathrm{Mn}$ on some fruit physical characteristics

\section{Average fruit weight and fruit size}

Data in Table (5) showed the effect of spraying with $\mathrm{B}, \mathrm{Ca}, \mathrm{Zn}, \mathrm{Cu}$ and $\mathrm{Mn}$ on average fruit weight and fruit size of Wonderful pomegranate cultivar in the two studied seasons. The maximum effect of average fruit weight $(\mathrm{g})$ and size $\left(\mathrm{cm}^{3}\right)$ with using calcium chloride at $4 \%$ followed by zinc sulphate at $0.4 \%$ in both seasons. This significantly increased fruit weight and size due to application of $\mathrm{Ca}$ which is important to every plant for their growth and development and is involved in activating the enzymes, inducing water movement and salt balance in plant cells, and also activating $\mathrm{K}$ to control the process of opening and closing of stomata (Hepler 2005). Yogeratnam and Greenham (1982) also reported that applying zinc to the trees might improve fruit quality such as fruit size by enhancing formation and translocation of carbohydrates and carbohydrate enzymes. Also, zinc plays many important regulatory roles in plant development through activating different enzymes, the biosynthesis of organic foods, cell division and cell enlargement (Yagodin, 1990). In this line Badawy et al. (2019) found that foliar application of "Manfalouty" pomegranate with $\mathrm{CaCl}_{2}$ at $2 \%$ twice on mid of June and August increased fruit weight as compared with control. Also, Abdelrhman et al., (2017) found that spraying of Manfalouty Pomegranate trees at the first week of March (growth start setting), May and June with $\mathrm{ZnSo}_{4}$ at $10 \mathrm{gL}^{-1}$ increased fruit weight (g.) as compared with control.

\section{Fruit length (cm) and fruit diameter (cm).}

Table (5) display obviously that different applied treatments (B, Ca, Zn, Cu and M) significantly increased fruit length $(\mathrm{cm})$ and diameter $(\mathrm{cm})$ compared to the control treatment for the two seasons. However, calcium chloride at $4 \%$ significantly increased fruit length $(\mathrm{cm})$ and fruit diameter $(\mathrm{cm})$, statistically followed by second significantly increased with using zinc sulphate at 0.4 during both 2018 and 2019 seasons. The increase of fruit length $(\mathrm{cm})$ and diameter $(\mathrm{cm})$ might be due to both the $\mathrm{Ca}$ and $\mathrm{Zn}$ ability in the division and elongation of the fruit cells. In this respect, Alloway (2008) reported that $\mathrm{Zn}$ Involvement in the synthesis of tryptophan which is a precursor of indole acetic acid synthesis, consequently it increased tissue growth and development. It has important role in starch metabolism, and acts as co-factor for many enzymes, affects photosynthesis reaction, nucleic acid metabolism and protein biosynthesis. The present result is in full agreement with that reported by Elakkad et al. (2016) who found that foliar application of Manfalouty pomegranate trees with $\mathrm{CaCl}_{2}$ at $80 \mathrm{ml} / 1$ at two months after fruit set increased fruit height $(\mathrm{cm})$ and fruit diameter as compared with control. Also, Hamouda et al. (2016) reported that foliar spraying Manfalouty pomegranate with Zn at 2000 ppm at mid of March, April and June increased fruit length and diameter $(\mathrm{cm})$.

\section{Fruit firmness $\left(\mathrm{g} / \mathrm{cm}^{2}\right)$, Peel thickness $(\mathrm{cm})$ and Juice volume $\left(\mathrm{cm}^{3}\right)$}

Data in Table (5) also showed that the highest fruit firmness $\left(\mathrm{g} / \mathrm{cm}^{2}\right)$ of the first and second seasons which were obtained from calcium chloride at $4 \%$ followed by calcium chloride at $2 \%$, zinc sulphate at $0.4 \%$ and zinc sulphate at $0.2 \%$. In contrast, the lowest fruit firmness $\left(\mathrm{g} / \mathrm{cm}^{2}\right)$ of the first and second seasons was obtained from control. The increase of fruit firmness $\left(\mathrm{g} / \mathrm{cm}^{2}\right)$ might be due to the fact that calcium has an essential role in plant structure and development. Before being absorbed by plants, calcium regulates the uptake of ions and adjusts the $\mathrm{pH}$ of soil (Quintero, 1991). Once in the plant system, calcium participates in polarity growth, secretion, hormonal actions, cell division, cationic transport, photosynthesis, gene expression, and many other processes. Most of these functions are achieved by interacting with calcium-related proteins such as Cacalmodulin which is the best known calciumbinding proteins (White and Broadley, 2003). In addition to these functions, about $60 \%$ of calcium is found the cell wall where pectic substances are abundant. It is known to perform a crucial role in determining cell 
structure and integrity, cell-to-cell adhesion, and tissue coherence (Poovaiah et al., 1988). Spraying of $1 \mathrm{~g}$ micronutrients $+0.3 \mathrm{ml} \mathrm{P} / \mathrm{L}$ (phosphoric acid/liter) at full bloom + fruit set significantly increased fruit firmness as compared with control (Singh and Usha 2001). Also, Calcium chloride $\left(\mathrm{CaCl}_{2}\right)$ has influence on the physical characteristics of fruits. In this respect, (Matas et al., 2009; Demuth and Sundrud 2012) reported that Calcium plays an important role in regulating the metabolism in apple fruit, and adequate calcium concentration maintains fruit firmness, delays fruit ripening, and internal breakdown.

Data in Table (5) also showed that the highest Peel thickness $(\mathrm{cm})$ of the first and second seasons was obtained from calcium chloride at $4 \%$ followed by zinc sulphate at $0.4 \%$. The present result is in full agreement with that reported by Karemera et al. (2014) who showed that the physical characteistic of fruits, Totapuri cV. recorded significantly higher fruit thickness when trees were sprayed with $1.50 \% \mathrm{CaCl}_{2}$ at 30 days before harvest. The increased Peel thickness $(\mathrm{cm})$ may be due to calcium chloride which could be attributed to its effects in influencing formation and changes of carbohydrates and carbohydrate enzymes, others reasons might be the reduction of abscission and the calcium influence in maintaining the middle lamella cells. The results obtained in the present investigation can be compared to those obtained by Wahdan et al. (2011).

Data in Table (5) also showed that the application of some spraying nutrients $(\mathrm{B}, \mathrm{Ca}$, $\mathrm{Zn}, \mathrm{Cu}$ and $\mathrm{Mn}$ ) gave significantly increase of volume of "Wonderful" fruit juice $\left(\mathrm{cm}^{3}\right)$ compared with that of control in both studied seasons. The highest Juice volume $\left(\mathrm{cm}^{3}\right)$ of the first and second seasons was obtained from zinc sulphate at $0.4 \%$ followed by calcium chloride at $4 \%$. The present result is in full agreement with that reported by Hasani et al. (2012) who found that foliar application of pomegranate tree with $\mathrm{Zns} 4$ at both levels (0.3) increased juice \% content as compared with control. On the other hand, Ahmed et al., (2014) found that spraying of Manfalouty Pomegranate trees at the first week of March, May and June with $\mathrm{CaCl}_{2}$ at $2 \%$ increased juice volume as compared with control.

It is concluded that foliar application with $\mathrm{B}, \mathrm{Ca}, \mathrm{Zn}, \mathrm{Cu}$ and $\mathrm{Mn}$ at different ranged increased fruit weight, fruit size, fruit length, fruit diameter, fruit firmness $\left(\mathrm{g} / \mathrm{cm}^{2}\right)$, Peel thickness $(\mathrm{cm})$ and Juice volume $\left(\mathrm{cm}^{3}\right)$ in comparison with that of untreated trees (control). The best foliar application was calcium chloride at $4 \%$ compared with the control and other treatments.

Effect of foliar spraying with B, Ca, Zn, Cu and $\mathrm{Mn}$ on fruit biochemical characteristics.

\section{Percentages of total soluble solids, total acidity and TSS/ Acid ratio.}

Table (6) showed that in both seasons, all treatments increased total soluble solids TSS (\%) as compared with the control. The highest values of T.S.S (\%) were obtained from zinc sulphate at $0.4 \%$ followed by descending calcium chloride at $4 \%$. Meanwhile, the lowest values of TSS (\%) in both seasons were obtained from control. These results are in line with those obtained by Hasani et al. (2012) who found that foliar application of pomegranate tree with Znso4 at $0.3 \%$ increased TSS\% and juice content as compared with control. Also, Badawy et al. (2019) found that foliar application of "Manfalouty" pomegranate with $\mathrm{CaCl}_{2}$ at $2 \%$ twice on mid of June and August increased T.S.S (\%) as compared with control. Moreover, Alrawi et al. (2012) reported that the increase in the percentage of total soluble solids when spraying Zn may be due to the role of these elements in increasing activities of the vegetative growth, then absorb nutrients. Also, the improvement in quality of fruit might be due to the fact that micronutrients directly play an important role in plant metabolism as zinc is needed in enzymatic reaction like hexokinase, formation of carbohydrate and protein synthesis (Pamila et al., 1992).

Table (6) showed that in both seasons all treatments decreased total acidity percentages as compared with the control. The highest values of total acidity (\%) in both seasons were obtained from control. Meanwhile, the lowest values of total acidity (\%) in both seasons were obtained from zinc sulphate at $0.4 \%$ followed by zinc sulphate at $0.2 \%$, calcium chloride at $4 \%$ and calcium chloride at $2 \%$. These results are in line with those obtained by Hamouda, et al. (2016) who reported that foliar spraying Manfalouty pomegranate with Zn at 2000 ppm at mid of March, April and June decreased total acidity $\%$ as compared with control. As well as, Elakkad et al. (2016) found that foliar application of Manfalouty pomegranate trees with $\mathrm{CaCl}_{2}$ at $80 \mathrm{ml} / 1$ at two months after fruit set decreased total acidity as compared with control.

Table (6) showed that the highest values of TSS/ acidity in the first and second seasons were obtained from zinc sulphate at $0.4 \%$ 
followed in descending by zinc sulphate at $0.2 \%$, calcium chloride at $4 \%$. Meanwhile, the lowest values of TSS/ acidity were obtained from control. The increase in TSS/Acidity is due to the increase in TSS and the decreased total acidity. These results are in line with those obtained by Abdelrhman et al. (2017) who found that spraying of Manfalouty Pomegranate trees at the first week of March (growth start setting), May and June with ZnSo4 at $10 \mathrm{gL}-1$ increased TSS. \% and decreased total acidity as compared with control. Also, Badawy et al. (2019) found that foliar application of "Manfalouty" pomegranate with $\mathrm{CaCl}_{2}$ at $2 \%$ twice increased T.S.S and decreased total acidity (\%) as compared with control.

\section{Ascorbic acid (VC) content $(\mathrm{mg} / 100 \mathrm{ml}$ of fruit juice)}

Data in tables (6) showed that all treatments increased Vitamin C when compared with that of control in the two studied seasons. The highest values of Vitamin $C$ were obtained from zinc sulphate at $0.4 \%$ followed by Zinc sulphate at $0.2 \%$, calcium chloride at $4 \%$ and Calcium chloride at $2 \%$ Whereas, the lowest values of vitamin $C$ were obtained from the control. These results are in line with those obtained by Hamouda et al. (2016) who reported that foliar spraying Manfalouty pomegranate with $\mathrm{Zn}$ at $2000 \mathrm{ppm}$ at mid of March, April and June increased VC as compared with control. Also, Amro (2015) found that foliar application of Valencia orange with $\mathrm{ZnsO} 4$ at $0.4 \%$ three times the $1^{\text {st }}$ spray was after fruit set, the $2^{\text {nd }}$ spray was at the mid of June and $3^{\text {rd }}$ was at the mid of August increased VC in comparison to the control. Similarly, Elakkad et al. (2016) found that foliar application of Manfalouty pomegranate trees with $\mathrm{CaCl} 2$ at $80 \mathrm{ml} / \mathrm{l}$ at two months after fruit set increased VC as compared with control.

\section{Total anthocyanin $\mathrm{mg} / 100 \mathrm{ml}$ in juice and peel}

Anthocyanins are a group of natural pigments responsible for the red-blue colors of many fruits and vegetables. They are of interest because in addition to their use as natural colorants, they also have important effect on human health (Fischer et al., 2013; Türkyilmaz, 2013; Radunic et al., 2015). Data in Tables (6) showed that all treatments increased Anthocyanin of juice $\mathrm{mg} / 100 \mathrm{ml}$ when compared with that of control in the two seasons. The highest values of Anthocyanin $\mathrm{mg} / 100 \mathrm{ml}$ of juice in 2018 season were obtained from zinc sulphate at $0.4 \%$ followed by calcium chloride at $4 \%$, Zinc sulphate at $0.2 \%$ and manganese sulphate at $0.4 \%$. Whereas, the highest values of Anthocyanin $\mathrm{mg} / 100 \mathrm{ml}$ of juice in 2019 season were obtained from zinc sulphate at $0.4 \%$ followed by calcium chloride at $4 \%$, manganese sulphate at $0.4 \%$ and manganese sulphate at $0.2 \%$. On the other hand, the lowest values of Anthocyanin $\mathrm{mg} / 100 \mathrm{ml}$ of juice were obtained from the control in 2018 and 2019 seasons.

Also, Data in tables (6) showed that all treatments increased Anthocyanin mg/100g fruit peel when compared with that of control in the two seasons. The highest values of Anthocyanin mg/100g of fruit peel in 2018 season were obtained from zinc sulphate at $0.4 \%$ followed by zinc sulphate at $0.2 \%$, calcium chloride at $4 \%$, and calcium chloride at $2 \%$. Whereas, the highest values of Anthocyanin mg/100ml of fruit peel in 2019 season were obtained from zinc sulphate at $0.4 \%$ followed by zinc sulphate at $0.2 \%$, calcium chloride at $4 \%$, and manganese sulphate at $0.4 \%$. on the other hand, the lowest values of Anthocyanin mg/100 g fruit peel were obtained from the control in 2018 and 2019 seasons. These results are in line with those obtained by Hamouda et al. (2016) who reported that foliar spraying of Manfalouty pomegranate with $\mathrm{Zn}$ at $2000 \mathrm{ppm}$ at the mid of March, April and June increased anthocyanins $\mathrm{mg} / \mathrm{L}$ and decreased total acidity $\%$ as compared with control. Also, Elakkad et al. (2016) found that foliar application of Manfalouty pomegranate trees with $\mathrm{CaCl}_{2}$ at $80 \mathrm{ml} / 1$ at two months after fruit set increased anthocyanins $\mathrm{mg} / \mathrm{L}$ as compared with control. Similarly, Badawy et al. (2019) found that foliar application of "Manfalouty" pomegranate with $\mathrm{CaCl}_{2}$ at $2 \%$ twice on the mid of June and August increased anthocyanin as compared with control. Hamouda et al., (2016) reported that foliar spraying Manfalouty pomegranate with Mn at 1600 ppm at mid of March, April and June increased anthocyanins $\mathrm{mg} / \mathrm{L}$ and decreased total acidity $\%$ as compared with control.

\section{Hue angle}

As shown in table (6), the hue angle of Wonderful cv., fruits were the lowest with all treatments in the two studied seasons. respectively. However, the highest hue angle was recorded control treatment. The result in table (6) showed that the highest hue angle in peel and arils was obtained from control in both seasons. On the other hand, the lowest hue angle in peel and arils was obtained from zinc sulphate at $0.4 \%$ followed by calcium 
chloride at $4 \%$ and Calcium chloride at $2 \%$ in the two studied seasons. The decrease of hue angle means that the external color developed from green to red as a result of the chlorophyll pigments decrease (McGuire, 1992).

We can come to conclusion that foliar application of "Wonderful" pomegranate with $\mathrm{B}, \mathrm{Ca}, \mathrm{Zn}, \mathrm{Cu}$ and $\mathrm{Mn}$ at different concentrations significantly increased TSS (\%), TSS/ acid ratio and VC (mg/100ml) of fruit juice, Anthocyanin mg/ml (juice) and mg/100g (peel) and the color in comparison with that of untreated tree (control). The best foliar application was obtained with zinc sulphate at $0.4 \%$ followed by calcium chloride at $4 \%$

\section{CONCLUSION}

We can come to concluded that foliar application of "Wonderful" pomegranate with $\mathrm{Ca}$ and $\mathrm{Zn}$ at different concentrations significantly increased the vegetative growth, fruiting, fruit quality and decreased fruit cracking, sunburn as compared with control.

\section{REFERENCES}

A.O.A.C. 2000. Association of Official Agricultural Chemists Official Methods of Analysis. 12 Ed. Washington, D.C. USA.

Abdelrahman, I.E. 2010. Physiological studies on cracking phenomena of Pomegranate. Journal of Applied Sinces Research, 6(6): 696-703.

Abdelrhman, I.E, Attia M.F, Elhady, E.S., Haggag, L.F. 2017. Effect of Foliar Spraying of Some Antioxidants and Micronutrients on Yield, Fruit Quality and Leaf Mineral Content of Manfaloty Pomegranate Trees (Punica Granatum L.) Grown in a Calcareous Soil. Middle East J. Appl. Sci., 7(4): 713-725.

Abdelnaby, A., Abdelkhalek, A.M., El-Naggar, Y.I. 2019. Effect of melatonin, GA3 and NAA on vegetative growth, yield and quality of 'Canino'apricot fruits. Acta Scientiarum Polonorum. Hortorum Cultus 18, 167-174.

Ahmed, F.F., Mohamed, M.M., Abou elkhashab, A.M.A., Aeed, S.H.A. 2014. Controlling fruit splitting and improving productivity of Manfalouty pomegranate trees by using salicylic acid and some nutrients. World Rural Observations, 6(1), 87-93.

Ahmed, F.F., Morsy, M.H. 1999.A new method for measuring leaf area in different fruit species. Minia. J. Agric. Res. \& Develop., 19: 97-105.

Ahmed, F.F., Shaaban, M.M., Abdelaal, A.M.K. 2011. Protecting crimson seedless grapevines growing in hot climates from sunburn. Research Journal of Agriculture and Biological Sciences, 7(1), 135-141.
Alloway, B.J. 2008. Zinc in soils and crop nutrition. Second edition, published by IZA and IFA Brussels, Belgium and Paris, France, 2008

Alrawi, W., Jassim, N.A., Al-Hadethi, M.E. 2012. Effect of iron and zinc spray on yield, growth and content of the seeds of apricot amygdalin. Egyptian Journal of Applied Sciences, 27(4): 173-187.

Alrawi, W.A, Jassim, N.A., Alhadethi, M.E.A. 2014. Effect of manganese and calcium foliar application on tree growth, yield and fruit quality of" Salimi" pomegranate cultivar. Zagazig J. Agric. Res, 41(5), 977-983.

Amro, S.M. 2015 Effect of Algae Extract and Zinc Sulfate Foliar Spray on Production and Fruit Quality of Orange Tree cv. Valencia. Journal of Agriculture and Veterinary Science (IOSRJAVS) 2319-2372. (8) 51-62.

Andrews, P.K., Johnson, J.R. 1996. Physiology of sunburn development in apples. Good Fruit Grower, 47(12), 33-36.

Andrews, P.K., Johnson, J.R. 1997. Anatomical changes and antioxidant levels in the peel of sunscald damaged apple fruit. Plant Physiol., (3) $103: 114$.

Ashraf, M.I., Shoukat, S., Bilal, H., Muhammad, S., Muhammad, A., Muhammad, I. 2018. Foliar application effect of boron, calcium and nitrogen on vegetative and reproductive attributes of tomato (Solanum lycopersicum L., J Agri Sci Food Res, 9:1

Ashraf, M.Y., Ashraf, M., Akhtar, M., Mahmood, K., Saleem, M. 2013. Improvement in yield, quality and reduction in fruit drop in kinnow (citrus reticulata blanco) by exogenous application of plant growth regulators, potassium and zinc. Pakistan Journal of Botany, 45(SI), 433-440.

Badawy, I.F., Abouzaid, E.A., Hussein, E.M. 2019. Cracking and fruit quality of" Manfalouty" pomegranate as affected by pre-harvest of Chitosan, Calcium chloride and Gibbrellic acid spraying. Middle East J, 8(3), 873-882.

Bakeer, S.M. 2016. Effect of ammonium nitrate fertilizer and calcium chloride foliar spray on fruit cracking and sunburn of Manfalouty pomegranate trees. Scientia Horticulturae, 209, 300-308.

Bankar, G.J., Prasad, R.N. 1992. Performance of important pomegranate cultivars in arid region. Annals Arid Zone. 31:181-03.

Barber, H.N., Sharpe, P.J.H. 1971. Genetics and physiology of sunscald fruits. Agric. Meteorol., 8 175:192.

Barker, A., Pilbeam, D. 2007. Handbook of plant nutrition. CRC Press, Taylor and Francis Group, Boca Raton, FL. 
Demuth, B., Sundrud, O. 2012. Determination of calcium, magnesium, and potassium in various apple samples using ICP-AES. Concordia College J. Anal. Chem. 3: 19-23.determination of total anthocyanin in cranberries. Journal of Food Science, 33:72-77.

Dickinson, K., Brien, J.O., Voet, L., Edwards, T. 2003. Metalosate "zinc in plant nutrition". Albion, 4(2): 1-4.

Elakkad, M.M., Gouda, F.E.Z.M., Ibrahim, R.A. 2016. Effect of $\mathrm{GA}_{3}$, calcium chloride and vapor guard spraying on yield and fruit quality of Manfalouty pomegranate trees. Assiut J. Agric. Sci, 6(1), 181-190.

Elmer, P.A.G., Spiers, T.M., Wood, P.N. 2007. Effects of pre-harvest foliar calcium sprays on fruit calcium levels and brown rot of peaches. Crop Protection, 26(1), 11-18.

Elsalhy, A.M. 1996. Performance of single and multiple Manfalouty Pomegranate fruits in response to GA3 application. 4th Arabic Conf. For Hort. Crops, EL-Minia, Egypt, 757-767.

Fischer, U.A., Carle, R., Kammerer, D.R. 2013. Thermal stability of anthocyanins and colourless phenolics in pomegranate (Punica granatum L.) juices and model solutions. Food Chemistry 138:1800-1809. doi:10.1016/ j. foodchem.2012.10.072.

Fuleki, T., Francis, F.J. 1968. Quantitative methods for anthocyanins. Determination of total anthocyanin and degradation index for cranberry juice. Journal of food science, 33(1), 7883.

Glenn, D.M., Prado, E., Erez, A., McFerson, J., Puterka, G.J. 2002. A reflective, processedkaolin particle film affects fruit temperature, radiation reflection, and solar injury in apple. Journal of the American Society for Horticultural Science, 127(2), 188-193.

Hamouda, H.A., Khalifa, R.K.M., El-Dahshouri, M.F., Zahran, N.G. 2016. Yield, fruit quality and nutrients content of pomegranate leaves and fruit as influenced by iron, manganese and zinc foliar spray. International Journal of Pharm Tech Research, 9(3), 46-57.

Harris, K.D., Lavanya, L. 2016. Influence of Foliar Application of Boron the quality of Tomato. Research Journal of Agriculture and Forest, 4(7), 1-5.

Hasani, M., Zamani, Z., Savaghebi, G., Fatahi, R. 2012. Effects of zinc and manganese as foliar spray on pomegranate yield, fruit quality and leaf minerals. Journal of soil science and plant nutrition, 12(3), 471-480.

Hegazi, A., Samra, N.R., Elbaz, E.E.T., Khalil, B.M., Gawish, M.S. 2014. Improving fruit quality of Manfaloty and Wonderful pomegranates by using bagging and some spray treatments with gibberellic acid, calcium chloride and kaolin. Journal of Plant Production, 5(5), 779-792.

Hepler, P.K. 2005. Calcium: a central regulator of plant growth and development. The Plant Cell, 17(8), 2142-2155.

Hifny, H.A., Fahmy, M.A., Bagdady, G.A., Abdrabboh, G.A., Hamdy, A.E. 2013. Effectof nitrogen fertilization added at various phenological stages on growth, yieldand fruit quality of Valencia orange trees. Nat. Sci. $11,220-229$.

Holland, D., Hatib, K., Bar-Ya'akov, I. 2009. Pomegranate: botany, Horticulture, Breeding. Horticultural reviews, 35(2), 127-191.

Ibrahim, Z.R. 2013. Effect of foliar spray of ascorbic acid, Zn, seaweed extracts (Sea) force and biofertilizers (EM-1) on vegetative growth and root growth of olive (Olea Europaea L.) transplants cv. HojBlanca. International Journal of Pure and Applied Sciences and Technology, 17(2), 79.

Jackman, R.L., Stanley, D.W. 1995. Perspectives in the textural evaluation of plant foods- trends food Sci. Vol. (6) 186-194.

Kader, A.A. 2006. Postharvest biology and technology of pomegranates. In: Seeram, N.P., et al. (Eds.), Pomegranates: Ancient Roots to Modern Medicine. CRC Press, Boca Raton, FL. CA, pp. 15-183.

Karemera, N.U., Mukunda, G.K., Ansar, H., Taj, A. 2014. Effect of calcium chloride sprays on ripening, shelf life, physico-chemical parameters and organoleptic evaluation of mango fruits (Mangifera indica L.) cv. Totapuri. Plant Archives, 14(1), 121-124.

Lal, S., Ahmed, N., Mir, J.I. 2011. Effect of different chemicals on fruit cracking in pomegranate under karewa condition of Kashmir Valley.

Matas, A.J., Gapper, N.E., Chung, M.Y., Giovannoni, J.J., Rose, J.K. 2009. Biology and genetic engineering of fruit maturation for enhanced quality and shelf-life. Current opinion in biotechnology, 20(2), 197-203.

McGuire, R.G. 1992. Reporting of objective color measurements. HortScience, 27(12), 1254-1255.

Mengel, K.E., Kirkby, A., Koesgarten, H., Appel. T. 2001. Principles of Plant Nutrition. 5th ElKluwer Academic Publishers, Dordrecht p.1311.

Mignani, I., Greve, I.C., Ben Arie, R., Stotz, H.U., Shockel, K., Labavitch, J. 1995. The effects of $\mathrm{GA}_{3}$ and divalent cations on aspects of pectin metabolism and tissue softening in ripening tomato Pericarp. Physiol. Plant, 93: 108-115.

Nijjar, G.S. 1985. Nutrition of fruit. Published by Mrsusha Rajkumer for Kalyeni publisher's New Delhi pp.10-270. 
Pamila, S., Chatterjee, S.R., Deb, D.L. 1992. Seed yield, harvest index, protein content and amino acid composition of chickpea as affected by Sulphur and micronutrients. Annals of Agriculture Research. 3(1):7-11.

Parmar, J.M., Karetha, K.M., Rathod, P.J. 2014. Effect of foliar spray of urea and zinc on growth and flowering attributes of guava (Psidium guajava) cv. BHAVNAGAR RED. Advance Research Journal of Crop Improvement, 5(2), 140-143.

Poovaiah, B.W. 1986. Role of calcium in prolonging storage life of fruits and vegetables Food Technol. 40, 86-89.

Poovaiah, B.W., Glenn, G.M., Reddy, A.S.N. 1988. Calcium and fruit softening: physiology and biochemistry. Hort. Rev, 10, 107-152.

Quintero, R.J.P. 1991. Chemical, physical, and sensory attributes of applesauce processed from apples pressure infiltrated with calcium chloride prior to storage. Knoxville: The University of Tennessee.

Radunić, M., Špika, M.J., Ban, S.G., Gadže, J., Díaz-Pérez, J.C., MacLean, D. 2015. Physical and chemical properties of pomegranate fruit accessions from Croatia. Food chemistry, 177, 53-60.

Randhawa, G.S., Singh, J.P., Malik, R.S. 1958. Fruit cracking in some tree fruits with special reference to lemon (Citrus limon). Indian Journal of Horticulture, 15(1), 6-9.

Ranganna, S. 1979. Manual of analysis of fruit and vegetable products. New Delhi India Tanta Mc Graw Hill Publishing Company. Limited Chapter 4: 77-83.

Ruck, J.A. 1969. Chemical methods for analysis of fruit and vegetable products. Research Branch, Canada Department of Agriculture, Canada.47 pp.

Sadamatsu, M. 1982. Occurrence of sun scald in early satsuma mandarin and its control. In Proceedings of the International Society of Citriculture / [International Citrus Congress, November 9-12, 1981, Tokyo, Japan; K. Matsumoto, editor]. Shimizu, Japan: International Society of Citriculture, 1982-1983.

Sadeghzadeh, B. 2013. A review of zinc nutrition and plant breeding. Journal of Soil Science and Plant Nutrition, 13: 905-927.

Schrader, L., Zhang, J., Sun, J. 2003. Environmental stresses that cause sunburn of apple. Acta Hort., 618, 397-405.

Sheikh, M.K., Manjula, N. 2012. Effect of chemicals on control of fruit cracking in pomegranate (Punica granatum L.) var.
Ganesh. In II International symposium on the pomegranate (pp. 133-1). CIHEAM/Universidad Miguel Hernández Zaragoza.

Singh, B., Usha, K. 2001. Effect of macro and micro-nutrient spray on fruit yield and quality of grape (Vitis vinifera L.) cv. Perlette. In International Symposium on Foliar Nutrition of Perennial Fruit Plants 594 (pp. 197-202).

Singh, D.B., Kingsly, A.R.P. 2006. Efficiency of boron application on control of fruit cracking and improvement in yield and quality of pomegranate fruits. In National Symposium on Improving Input Use Efficiency in Horticulture held during (pp. 9-1).

Singh, D.K., Paul, P.K., Ghosh, S.K. 2005. Response of papaya to foliar application of boron, zinc and their combinations. Res. Crops, 6(2): 277-280.

Snedecor, G.W., Cochran, W.G. 1980 Statistical Methods, 6th ed., Iowa State Univ., Amess, lowa. USA.

Stern, R.D. 1991. Review of 'CoStat- Statutical Software' Experimental Agriculture, 27, pp 8787.

Sutanu, M., Aniruddha, Y., Meena, K.R. 2017. Effect of calcium and boron on growth, yield and quality of pomegranate (Punica granatum L.). International Journal of Plant Sciences (Muzaffarnagar), 12(2), 108-113.

Tony, W., John, C. 1994. All about cherry cracking. Tree fruit leader, Vol. 3 (2): July 1994.

Türkyılmaz, M. 2013. Anthocyanin and organic acid profiles of pomegranate (Punica granatum L.) juices from registered varieties in Turkey. International journal of food science \& technology, 48(10), 2086-2095.

Turrel, F.M. 1946. Tables of surfaces and volume of spheres and of prolate and oblate Spheroids spheroidal coefficients Univ. Calif. Press, Barkely USA.

Wahdan, M.T., Habib, S.E., Bassal, M.A., Qaoud, E.M. 2011. Effect of some chemicals on growth, fruiting, yield and fruit quality of" Succary Abiad" mango cv. Journal of American Science, 7(2), 651-658.

White, P.J., Broadley, M.R. 2003. Calcium in plants. Annals of botany, 92(4), 487-511.

Yagodin, B.A. 1990. Agriculture chemistry Mir Publishers Moscow pp. 278-281.

Yogeratnam, N., Greenham D.W.P. 1982. The application of foliar sprays containing $\mathrm{N}, \mathrm{Mg}$, $\mathrm{Zn}$ and $\mathrm{B}$ to apple trees. I. Effect on fruit set and cropping. J. Horticult. Sci. 57(2): 151-154. 
Table 1. Effect of some nutrients on vegetative growth [shoot length, number of leaves / shoots, leaf area $\left(\mathrm{cm}^{2}\right)$ and canopy volume $\left(\mathrm{m}^{3}\right)$ ] of "Wonderful" trees in 2018 and 2019 seasons.

\begin{tabular}{ccccccccc}
\hline Character. & \multicolumn{2}{c}{$\begin{array}{c}\text { Shoot length } \\
(\mathrm{cm})\end{array}$} & \multicolumn{3}{c}{$\begin{array}{c}\text { Number of } \\
\text { leaves / shoot }\end{array}$} & Leaf area $\left(\mathrm{cm}^{2}\right)$ & $\begin{array}{c}\text { Canopy } \\
\text { volume }\left(\mathrm{m}^{3}\right)\end{array}$ \\
\cline { 2 - 10 } & \multicolumn{3}{c}{ season } \\
\cline { 2 - 9 } Treatment & 2018 & 2019 & 2018 & 2019 & 2018 & 2019 & 2018 & 2019 \\
\hline Control & 18.28 & 19.66 & 20.47 & 19.47 & 4.27 & 5.18 & 7.33 & 8.04 \\
Boric acid at 0.5\% & 24.76 & 26.09 & 23.77 & 25.10 & 5.65 & 6.66 & 8.49 & 9.25 \\
Boric acid at 1\% & 28.07 & 29.40 & 26.01 & 28.01 & 7.27 & 7.78 & 9.90 & 10.57 \\
Calcium chloride at 2\% & 30.28 & 32.94 & 27.40 & 30.97 & 8.75 & 9.01 & 11.66 & 12.17 \\
Calcium chloride at 4\% & 38.10 & 39.77 & 33.18 & 38.11 & 11.25 & 11.94 & 12.94 & 13.81 \\
Zinc sulphate at 0.2\% & 32.13 & 34.80 & 28.15 & 31.52 & 8.46 & 8.77 & 11.94 & 12.21 \\
Zinc sulphate at 0.4\% & 35.21 & 36.21 & 30.92 & 35.92 & 9.74 & 10.18 & 12.52 & 13.05 \\
Copper sulphate at 0.2\% & 28.61 & 29.61 & 26.35 & 28.61 & 6.87 & 6.90 & 9.89 & 10.26 \\
Copper sulphate at 0.4\% & 29.70 & 31.26 & 27.10 & 29.84 & 7.38 & 8.00 & 10.09 & 10.63 \\
Manganese sulphate at 0.2\% & 27.08 & 27.41 & 26.37 & 26.97 & 8.12 & 8.83 & 8.82 & 9.48 \\
Manganese sulphate at 0.4\% & 30.08 & 32.41 & 28.40 & 30.06 & 8.59 & 8.70 & 11.24 & 12.25 \\
LSD at 5\% & 1.98 & 1.50 & 1.00 & 1.22 & 0.19 & 0.39 & 0.12 & 0.24 \\
\hline
\end{tabular}

Table 2. Effect of some nutrients on fruiting of "Wonderful" trees in 2018 and 2019 seasons.

\begin{tabular}{|c|c|c|c|c|c|c|c|c|c|c|}
\hline \multirow{3}{*}{$\begin{array}{l}\text { Character. } \\
\text { Treatment }\end{array}$} & \multirow{2}{*}{\multicolumn{2}{|c|}{$\begin{array}{c}\text { Initial fruit set } \\
(\%)\end{array}$}} & \multirow{2}{*}{\multicolumn{2}{|c|}{$\begin{array}{c}\text { Fruit retention } \\
(\%)\end{array}$}} & \multicolumn{2}{|c|}{ Fruit drop (\%) } & \multicolumn{2}{|c|}{ Yield $(\mathrm{kg} /$ tree $)$} & \multicolumn{2}{|c|}{$\begin{array}{l}\text { Increase }(\%) \text { in yield } \\
\text { than control. }\end{array}$} \\
\hline & & & & & \multicolumn{2}{|c|}{ season } & & & & \\
\hline & 2018 & 2019 & 2018 & 2019 & 2018 & 2019 & 2018 & 2019 & 2018 & 2019 \\
\hline Control & 55.30 & 58.64 & 58.27 & 61.93 & 41.73 & 38.07 & 50.79 & 55.45 & 0.00 & 0.00 \\
\hline Boric acid at $0.5 \%$ & 60.27 & 64.94 & 78.48 & 80.81 & 21.52 & 19.19 & 67.73 & 72.32 & 33.41 & 30.40 \\
\hline Boric acid at $1 \%$ & 65.47 & 70.14 & 73.77 & 74.44 & 26.23 & 25.56 & 64.06 & 68.82 & 26.18 & 24.12 \\
\hline Calcium chloride at $2 \%$ & 67.20 & 73.20 & 81.37 & 83.31 & 18.63 & 16.69 & 78.41 & 84.08 & 54.41 & 51.65 \\
\hline Calcium chloride at $4 \%$ & 71.02 & 77.69 & 88.35 & 87.25 & 11.65 & 12.75 & 98.94 & 105.84 & 94.86 & 90.86 \\
\hline Zinc sulphate at $0.2 \%$ & 68.31 & 74.65 & 84.04 & 82.44 & 15.96 & 17.56 & 83.65 & 89.43 & 64.70 & 61.28 \\
\hline Zinc sulphate at $0.4 \%$ & 69.85 & 75.52 & 85.89 & 84.55 & 14.11 & 15.45 & 89.55 & 96.22 & 76.41 & 73.55 \\
\hline Copper sulphate at $0.2 \%$ & 62.95 & 66.62 & 62.29 & 65.63 & 37.71 & 34.37 & 66.89 & 72.46 & 31.75 & 30.67 \\
\hline Copper sulphate at $0.4 \%$ & 64.20 & 69.20 & 64.15 & 68.15 & 35.85 & 31.85 & 70.71 & 75.67 & 36.22 & 36.47 \\
\hline Manganese sulphate at $0.2 \%$ & 60.74 & 61.40 & 65.80 & 70.47 & 34.20 & 29.53 & 73.81 & 78.47 & 45.39 & 41.51 \\
\hline Manganese sulphate at $0.4 \%$ & 62.93 & 66.60 & 67.71 & 74.05 & 32.29 & 25.95 & 75.19 & 80.86 & 48.08 & 45.83 \\
\hline LSD at $5 \%$ & 0.77 & 2.95 & 1.01 & 1.54 & 1.01 & 1.54 & 2.00 & 2.08 & 7.09 & 4.19 \\
\hline
\end{tabular}

Table 3. Effect of some nutrients on fruit cracking (\%) of "Wonderful" trees in 2018 and 2019 seasons.

\begin{tabular}{ccccccc}
\hline Character. & \multicolumn{7}{c}{$\begin{array}{c}\text { 2 } \\
\text { weeks before } \\
\text { harvest time }\end{array}$} & $\begin{array}{c}\text { At cracking\% } \\
\text { At harvest time }\end{array}$ & $\begin{array}{c}\text { 2 weeks after } \\
\text { harvest time }\end{array}$ \\
\cline { 2 - 6 } Treatment & \multicolumn{7}{c}{ season } \\
\cline { 2 - 6 } Control & 2018 & 2019 & 2018 & 2019 & 2018 & 2019 \\
\hline Boric acid at 0.5\% & 19.46 & 17.39 & 24.63 & 22.80 & 29.63 & 31.62 \\
Boric acid at 1\% & 14.59 & 13.04 & 17.12 & 14.99 & 21.10 & 20.54 \\
Calcium chloride at 2\% & 12.98 & 12.34 & 15.32 & 14.02 & 18.29 & 18.22 \\
Calcium chloride at 4\% & 11.10 & 9.89 & 12.73 & 10.70 & 14.51 & 12.89 \\
Zinc sulphate at 0.2\% & 7.09 & 5.72 & 8.14 & 6.79 & 9.24 & 9.04 \\
Zinc sulphate at 0.4\% & 11.60 & 10.98 & 13.16 & 12.38 & 16.14 & 16.17 \\
Copper sulphate at 0.2\% & 9.68 & 6.78 & 11.60 & 8.59 & 13.73 & 10.90 \\
Copper sulphate at 0.4\% & 12.00 & 11.83 & 15.18 & 14.07 & 17.96 & 19.99 \\
Manganese sulphate at 0.2\% & 10.97 & 8.43 & 13.73 & 9.92 & 16.71 & 11.39 \\
Manganese sulphate at 0.4\% & 13.62 & 12.61 & 15.78 & 14.95 & 19.75 & 20.97 \\
LSD at 5\% & 11.98 & 11.04 & 15.68 & 12.47 & 18.64 & 16.71 \\
& 1.09 & 0.47 & 0.96 & 0.32 & 0.84 & 0.73 \\
\hline
\end{tabular}


Table 4. Effect of some nutrients on sunburn (\%), marketable and unmarketable fruits of "Wonderful" trees in 2018 and 2019 seasons.

\begin{tabular}{|c|c|c|c|c|c|c|}
\hline \multirow{3}{*}{$\begin{array}{l}\text { Character } \\
\text { Treatment }\end{array}$} & \multicolumn{2}{|c|}{ Sunburn (\%) } & \multicolumn{2}{|c|}{ Marketable fruits } & \multicolumn{2}{|c|}{ Unmarketable fruits } \\
\hline & \multicolumn{6}{|c|}{ season } \\
\hline & 2018 & 2019 & 2018 & 2019 & 2018 & 2019 \\
\hline Control & 32.89 & 27.23 & 42.48 & 49.97 & 57.52 & 50.03 \\
\hline Boric acid at $0.5 \%$ & 28.11 & 24.26 & 54.77 & 60.80 & 45.23 & 39.20 \\
\hline Boric acid at $1 \%$ & 26.51 & 19.82 & 58.17 & 66.03 & 41.83 & 33.97 \\
\hline Calcium chloride at $2 \%$ & 14.46 & 10.77 & 72.81 & 78.39 & 27.19 & 21.61 \\
\hline Calcium chloride at $4 \%$ & 12.42 & 6.83 & 79.44 & 86.42 & 20.56 & 13.58 \\
\hline Zinc sulphate at $0.2 \%$ & 16.63 & 12.77 & 70.21 & 74.74 & 29.79 & 25.26 \\
\hline Zinc sulphate at $0.4 \%$ & 16.28 & 12.13 & 72.12 & 79.36 & 27.88 & 20.64 \\
\hline Copper sulphate at $0.2 \%$ & 25.39 & 18.76 & 59.43 & 67.23 & 40.57 & 32.77 \\
\hline Copper sulphate at $0.4 \%$ & 22.83 & 15.97 & 63.44 & 74.12 & 36.56 & 25.88 \\
\hline Manganese sulphate at $0.2 \%$ & 19.75 & 14.61 & 64.46 & 70.35 & 35.54 & 29.65 \\
\hline Manganese sulphate at $0.4 \%$ & 17.73 & 12.92 & 66.59 & 74.59 & 33.41 & 25.41 \\
\hline LSD at $5 \%$ & 1.42 & 0.42 & 1.70 & 0.35 & 1.70 & 0.35 \\
\hline
\end{tabular}

Table 5. Effect of some nutrients on some fruit physical characteristics of "Wonderful" pomegranate in 2018 and 2019 seasons.

\begin{tabular}{|c|c|c|c|c|c|c|c|}
\hline $\begin{array}{l}\text { Character. } \\
\text { Treatment }\end{array}$ & $\begin{array}{c}\text { Fruit } \\
\text { weight } \\
\text { (g) }\end{array}$ & $\begin{array}{l}\text { Fruit } \\
\text { size } \\
\left(\mathrm{cm}^{3}\right) \\
\end{array}$ & $\begin{array}{c}\text { Fruit } \\
\text { length } \\
\left(\mathrm{cm}^{2}\right) \\
\end{array}$ & $\begin{array}{c}\text { Fruit } \\
\text { diameter } \\
\left(\mathrm{cm}^{2}\right)\end{array}$ & $\begin{array}{c}\text { Fruit } \\
\text { firmness. } \\
\mathrm{g} / \mathrm{cm}^{2} \\
\end{array}$ & $\begin{array}{c}\text { Peel } \\
\text { thickness } \\
(\mathrm{cm})\end{array}$ & $\begin{array}{c}\text { Juice } \\
\text { volume } \\
\mathrm{cm}^{3}\end{array}$ \\
\hline \multicolumn{8}{|c|}{ Season 2018} \\
\hline Control & 361.31 & 321.09 & 7.80 & 7.37 & 403.53 & 0.43 & 113.14 \\
\hline Boric acid at $0.5 \%$ & 365.83 & 331.15 & 8.50 & 7.87 & 423.19 & 0.47 & 122.23 \\
\hline Boric acid at $1 \%$ & 371.69 & 369.94 & 9.03 & 8.23 & 440.86 & 0.54 & 129.27 \\
\hline Calcium chloride at $2 \%$ & 374.22 & 378.20 & 9.77 & 8.70 & 491.19 & 0.69 & 136.15 \\
\hline Calcium chloride at $4 \%$ & 382.81 & 412.20 & 10.83 & 9.23 & 521.81 & 0.74 & 143.68 \\
\hline Zinc sulphate at $0.2 \%$ & 373.13 & 363.26 & 9.50 & 8.37 & 467.58 & 0.60 & 138.66 \\
\hline Zinc sulphate at $0.4 \%$ & 379.91 & 392.06 & 9.97 & 8.70 & 480.87 & 0.65 & 144.99 \\
\hline Copper sulphate at $0.2 \%$ & 367.38 & 329.14 & 8.70 & 7.87 & 428.88 & 0.52 & 125.81 \\
\hline Copper sulphate at $0.4 \%$ & 369.26 & 338.27 & 9.07 & 8.10 & 446.79 & 0.54 & 127.27 \\
\hline Manganese sulphate at $0.2 \%$ & 371.48 & 320.16 & 8.70 & 7.83 & 422.70 & 0.54 & 128.74 \\
\hline Manganese sulphate at $0.4 \%$ & 372.30 & 337.04 & 9.13 & 8.73 & 451.94 & 0.57 & 129.63 \\
\hline LSD 5\% & 1.13 & 3.53 & 0.18 & 0.19 & 2.17 & 0.008 & 1.09 \\
\hline \multicolumn{8}{|c|}{ Season 2019} \\
\hline Control & 372.65 & 318.76 & 8.07 & 7.17 & 413.53 & 0.51 & 119.83 \\
\hline Boric acid at $0.5 \%$ & 377.50 & 350.48 & 8.60 & 7.70 & 437.52 & 0.56 & 129.47 \\
\hline Boric acid at $1 \%$ & 384.69 & 382.11 & 9.20 & 7.93 & 450.92 & 0.61 & 136.43 \\
\hline Calcium chloride at $2 \%$ & 389.89 & 391.20 & 10.23 & 8.47 & 507.36 & 0.73 & 144.4 \\
\hline Calcium chloride at $4 \%$ & 400.14 & 435.87 & 10.67 & 8.93 & 540.45 & 0.78 & 151.57 \\
\hline Zinc sulphate at $0.2 \%$ & 386.13 & 381.26 & 9.73 & 8.10 & 487.38 & 0.65 & 146.23 \\
\hline Zinc sulphate at $0.4 \%$ & 396.24 & 412.72 & 10.40 & 8.57 & 499.20 & 0.70 & 153.87 \\
\hline Copper sulphate at $0.2 \%$ & 379.28 & 347.47 & 8.97 & 7.70 & 443.55 & 0.58 & 133.03 \\
\hline Copper sulphate at $0.4 \%$ & 380.49 & 355.93 & 9.57 & 7.90 & 458.15 & 0.62 & 132.3 \\
\hline Manganese sulphate at $0.2 \%$ & 382.81 & 357.49 & 8.83 & 7.63 & 433.04 & 0.60 & 133.43 \\
\hline Manganese sulphate at $0.4 \%$ & 383.63 & 359.71 & 9.40 & 8.33 & 462.47 & 0.64 & 135.07 \\
\hline LSD 5\% & 0.88 & 1.76 & 0.09 & 0.11 & 1.70 & 0.009 & 1.58 \\
\hline
\end{tabular}


Table 6. Effect of foliar spraying with some nutrients on fruit biochemical characteristics and hue angle of Wonderful pomegranate in 2018 and 2019 seasons.

\begin{tabular}{|c|c|c|c|c|c|c|c|c|}
\hline \multirow{2}{*}{$\begin{array}{l}\text { Character. } \\
\text { Treatment }\end{array}$} & \multirow[b]{2}{*}{$\begin{array}{l}\text { TSS } \\
(\%)\end{array}$} & \multirow[b]{2}{*}{$\begin{array}{l}\text { Total } \\
\text { acidity } \\
(\%)\end{array}$} & \multirow[b]{2}{*}{$\begin{array}{l}\mathrm{TSS} / \\
\text { Acid } \\
\text { ratio }\end{array}$} & \multirow{2}{*}{$\begin{array}{c}\mathrm{VC} \mathrm{mg} \\
/ 100 \mathrm{ml} \\
\text { of fruit } \\
\text { juice }\end{array}$} & \multicolumn{2}{|c|}{ Anthocyanin } & \multicolumn{2}{|c|}{ Hue angle } \\
\hline & & & & & $\begin{array}{l}\mathrm{mg} / 100 \mathrm{~m} \\
1 \text { of Juice }\end{array}$ & $\begin{array}{c}\mathrm{mg} / 100 \mathrm{~g} \\
\text { of Peel }\end{array}$ & Peel & Arils \\
\hline \multicolumn{9}{|c|}{ season 2018} \\
\hline Control & 15.17 & 1.95 & 7.79 & 23.23 & 18.67 & 15.20 & 359.81 & 359.20 \\
\hline Boric acid at $0.5 \%$ & 15.97 & 1.71 & 9.34 & 26.67 & 20.50 & 16.10 & 351.60 & 344.57 \\
\hline Boric acid at $1 \%$ & 16.53 & 1.63 & 10.16 & 29.10 & 21.83 & 16.73 & 347.50 & 340.60 \\
\hline Calcium chloride at $2 \%$ & 16.97 & 1.55 & 10.95 & 32.03 & 23.63 & 17.57 & 341.53 & 333.90 \\
\hline Calcium chloride at $4 \%$ & 17.53 & 1.45 & 12.12 & 33.90 & 26.00 & 19.30 & 337.27 & 330.83 \\
\hline Zinc sulphate at $0.2 \%$ & 17.50 & 1.40 & 12.50 & 36.17 & 25.30 & 20.50 & 341.60 & 337.07 \\
\hline Zinc sulphate at $0.4 \%$ & 18.63 & 1.36 & 13.70 & 38.00 & 28.57 & 21.63 & 333.33 & 327.73 \\
\hline Copper sulphate at $0.2 \%$ & 16.73 & 1.48 & 11.31 & 28.93 & 22.67 & 15.70 & 351.37 & 345.20 \\
\hline Copper sulphate at $0.4 \%$ & 17.10 & 1.72 & 9.94 & 28.63 & 22.23 & 16.00 & 353.77 & 348.77 \\
\hline Manganese sulphate at $0.2 \%$ & 17.37 & 1.63 & 10.66 & 26.20 & 23.63 & 17.23 & 350.60 & 344.60 \\
\hline Manganese sulphate at $0.4 \%$ & 17.50 & 1.65 & 10.61 & 27.23 & 24.87 & 17.50 & 347.33 & 343.43 \\
\hline LSD 5\% & 0.27 & 0.01 & 0.21 & 1.20 & 0.23 & 0.41 & 0.58 & 0.41 \\
\hline \multicolumn{9}{|c|}{ season 2019} \\
\hline Control & 13.57 & 2.37 & 5.74 & 25.32 & 19.53 & 16.49 & 359.53 & 357.20 \\
\hline Boric acid at $0.5 \%$ & 14.50 & 2.09 & 6.94 & 28.84 & 23.57 & 19.22 & 348.57 & 340.90 \\
\hline Boric acid at $1 \%$ & 15.43 & 2.00 & 7.69 & 31.54 & 25.53 & 20.34 & 344.77 & 337.43 \\
\hline Calcium chloride at $2 \%$ & 16.00 & 1.90 & 8.42 & 33.96 & 28.95 & 21.45 & 337.87 & 331.20 \\
\hline Calcium chloride at $4 \%$ & 16.43 & 1.68 & 9.77 & 35.31 & 32.49 & 24.04 & 333.77 & 327.43 \\
\hline Zinc sulphate at $0.2 \%$ & 17.53 & 1.64 & 10.68 & 37.68 & 30.44 & 25.29 & 339.60 & 333.93 \\
\hline Zinc sulphate at $0.4 \%$ & 18.10 & 1.58 & 11.53 & 39.58 & 34.58 & 28.38 & 329.67 & 324.00 \\
\hline Copper sulphate at $0.2 \%$ & 15.47 & 1.83 & 8.48 & 29.33 & 27.57 & 17.58 & 348.03 & 341.70 \\
\hline Copper sulphate at $0.4 \%$ & 15.93 & 2.00 & 7.96 & 30.29 & 28.05 & 18.37 & 351.10 & 344.43 \\
\hline Manganese sulphate at $0.2 \%$ & 14.87 & 2.16 & 6.89 & 28.45 & 30.63 & 21.54 & 346.93 & 340.93 \\
\hline Manganese sulphate at $0.4 \%$ & 15.57 & 2.18 & 7.17 & 30.77 & 31.87 & 22.42 & 344.33 & 339.67 \\
\hline LSD $5 \%$ & 0.27 & 0.09 & 0.42 & 1.11 & 0.57 & 0.21 & 0.92 & 0.83 \\
\hline
\end{tabular}

\section{تأثير بعض العناصر الغذائة على نمو ومحصول وجودة مثمار الرمان صنف وندرفل

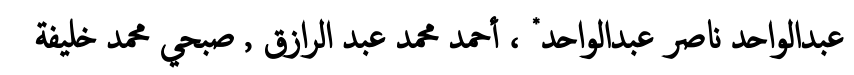

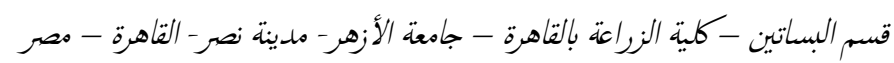

abdelwahedabdelwahed485.el @azhar.edu.eg البريد الاككترونى للباحث الرئيسي

$$
\text { الملخص العربى }
$$

ان التشتق و لفحة الشمس والخفاض اللون في الثخار من أهم المشاكل التى تواجه زراعة الرمان صنف وندرفل. كما أن لها دورا هاما في تحديد جودة

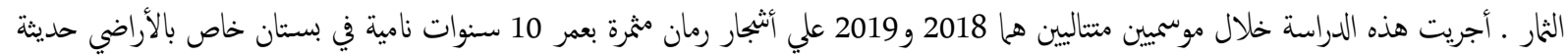

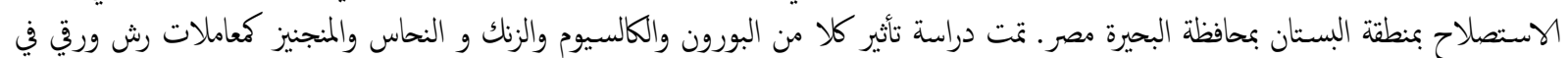

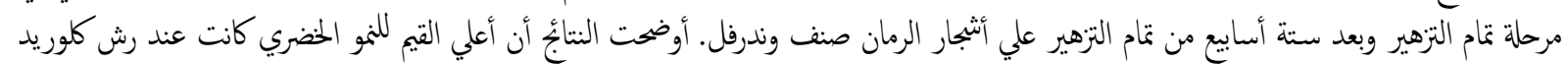

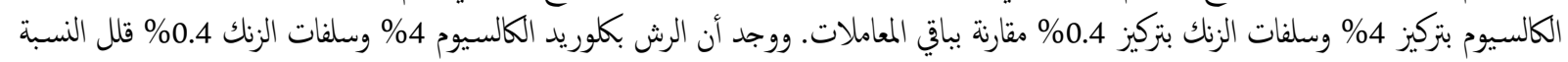

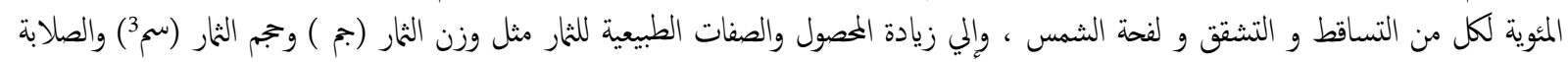

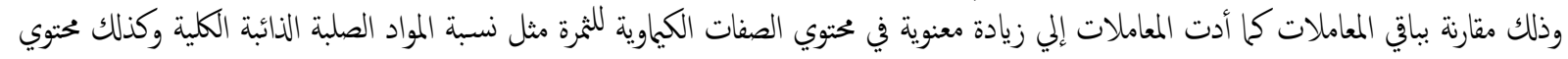

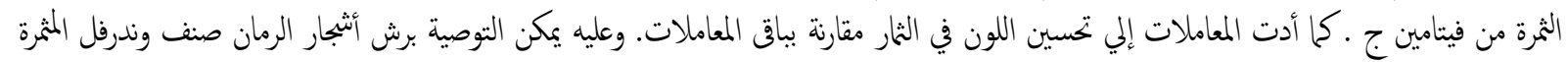

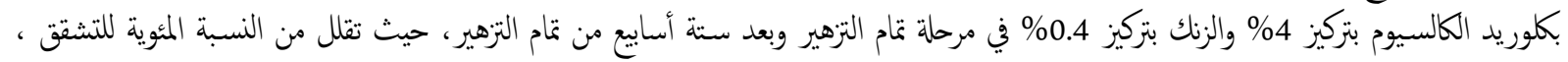

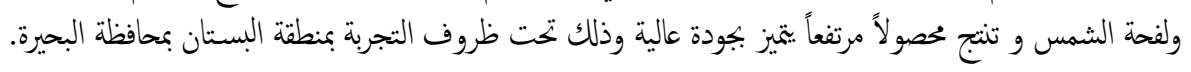

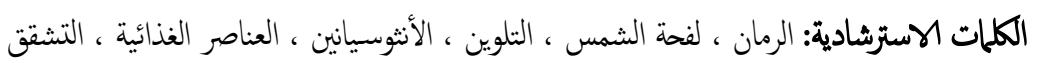

